\title{
Profil bakteri non spesifik dalam lendir serviks sapi perah pada fase folikuler dan fase luteal
}

\section{Profile of non-specific bacteria in the cervical mucus of dairy cattle in the follicular and luteal phase}

\author{
Maysarah Oktavia Nur ${ }^{*}$, Sri Mulyati ${ }^{2}$, Sri Chusniati ${ }^{3}$, Trilas Sardjito², \\ Wiwiek Tyasningsih $^{3}$, Maslichah Mafruchati ${ }^{4}$ \\ ${ }^{1}$ Mahasiswa, ${ }^{2}$ Departemen Reproduksi Veteriner, ${ }^{3}$ Departemen Mikrobiologi Veteriner, \\ ${ }^{4}$ Departemen Anatomi Veteriner, Fakultas Kedokteran Hewan, Universitas Airlangga \\ *Penulis koresponden, e-mail: mysarah.oktavia@gmail.com
}

\begin{abstract}
This research was conducted to identify non-specific bacteria found in the cervical mucus of dairy cattle in the follicular and luteal phase. Twenty cervical mucus samples were collected from ten cows during their follicular phase and ten cows during their luteal phase. Sampling was carried out with the help of an artificial insemination gun and a plastic sheath, which were protected by a sheath cover. After insertion into cervix, the tip of the plastic sheath was cut and put into a tube prefilled with phosphate buffered saline. All samples were cultured in Blood Agar media and isolated in Eosin Methylene Blue Agar, Mac Conkey Agar, and Manitol Salt Agar. Gram staining was applied to distinguish gram-positive and gram-negative bacteria; and followed with the catalase, spore, motility, and biochemical tests to further identify bacteria. The bacteria identified were of the genus Enterobacter, Staphylococcus, Corynebacterium, Streptococcus, Escherichia, and Pasteurella. It could be concluded that non-specific bacteria of the same genus were identified in cervical mucus of dairy cows in their follicular and luteal phase, in a various of percentages.
\end{abstract}

Keywords: dairy cattle, follicular phase, luteal phase, cervical mucus, non-specific bacteria

\section{PENDAHULUAN}

Produksi susu di Indonesia belum bisa mencukupi kebutuhan susu nasional. Jumlah peternak susu di Indonesia masih sedikit yakni berkisar 118,75 ribu peternak (Sanny, 2011). Sistem pemeliharaan sapi perah di Indonesia rata-rata masih menggunakan sistem pemeliharaan berskala kecil dan tradisional. Di Indonesia pemerataan peternak sapi perah juga masih belum sempurna. Peningkatan produksi susu dapat dilakukan dengan meningkatkan produktivitas atau populasi dari sapi perah laktasi (Wahyuni, 2012).

Produktivitas sapi perah untuk menghasilkan susu sangat tergantung pada lancarnya keberlangsungan siklus reproduksi, karena produksi susu merupakan bagian tidak terpisahkan dari siklus reproduksi itu sendiri. Kendala yang sering dijumpai dalam dunia peternakan adalah gangguan reproduksi yang berpengaruh langsung terhadap status kesehatan reproduksi. Gangguan reproduksi yang diakibatkan antara lain oleh bakteri dapat menimbulkan infertilitas sampai sterilitas (Hariadi et al., 2011).

Di Indonesia, dari 20,4\% kasus gangguan reproduksi pada sapi perah, 2-5\% diduga disebabkan oleh infeksi bakteri. Gangguan reproduksi dapat disebabkan oleh berbagai mikroorganisme, antara lain bakteri (Brucella sp., Vibrio sp., Staphylococcus sp.), virus, infeksi mycoplasma dan jamur (Hariadi et al., 2011). Bakteri yang dapat menyebabkan infeksi pada saluran reproduksi ternak, khususnya pada uterus bisa dibedakan menjadi dua kelompok yaitu bakteri non spesifik dan bakteri spesifik (Hafez dan Hafez, 2000). Bakteri non spesifik yang berada di dalam uterus dalam jumlah yang cukup besar adalah Streptococcus sp., Staphylococcus sp., E. coli, dan Pseudomonas aeruginosa yang dapat menimbulkan 
peradangan uterus atau induk sapi menderita kawin berulang, siklus birahi berlangsung normal, namun berulang kali dikawinkan tidak menghasilkan kebuntingan (Hariadi et al., 2011).

Siklus birahi pada sapi terdiri atas dua fase yaitu fase folikuler yang meliputi proestrus, dan estrus, dan fase luteal yang meliputi metestrus dan diestrus. Fase folikuler diawali saat korpus luteum lisis, kadar progesteron menurun, pertumbuhan folikel mulai aktif, dan mensekresikan secara bertahap estrogen sesuai dengan perkembangan folikel. Peningkatan estrogen akan menimbulkan terjadinya tingkah laku birahi dan meningkatkan kadar FSH sampai terjadi ovulasi. Fase luteal dicirikan oleh aktifnya korpus luteum mensekresikan progesteron, sehingga level progesteron tinggi, sedangkan LH dan FSH rendah. Serviks berfungsi sebagai pintu yang menghubungkan vagina dengan lumen uterus (Ismudiono et al., 2010). Pada masa birahi, akibat kadar estrogen yang tinggi menyebabkan serviks mengalami dilatasi dan sel-sel goblet serviks menghasilkan lendir serviks yang encer dan transparan yang meleleh keluar dari vulva. Sedangkan pada fase luteal kadar progesteron yang tinggi menyebabkan cincin-cincin servix menutup dan sel-sel goblet serviks menghasilkan lendir yang pekat untuk mencegah mikroorganisme memasuki lumen uterus (Hafez dan Hafez, 2000).

Penelitian terdahulu (Fadhilla, 2018) mengidentifikasi adanya bakteri non spesifik Escherischia sp., Staphylococcus sp., dan Corynebacterium sp. pada saluran reproduksi sapi perah di Peternakan di Bendul Merisi, Surabaya tanpa membedakan fase birahinya. Sehubungan dengan hal tersebut maka penelitian ini bertujuan untuk mengetahui genus bakteri non spesifik yang terdapat pada lendir serviks sapi perah dalam fase folikuler dan fase luetal.

\section{MATERI DAN METODE}

Penelitian ini menggunakan 20 ekor sapi perah dari peternakan sapi perah di Bendul Merisi, Surabaya. Sampel lendir serviks fase folikuler diambil dari 10 ekor sapi pada saat sapi sedang birahi, sedangkan lendir serviks fase luteal diambil dari 10 ekor sapi, tiga hari setelah sapi dikawinkan. Data yang diperoleh disajikan dalam bentuk deskriptif.

\section{Sampel penelitian}

Sampel lendir diambil menggunakan laras inseminasi buatan (artificial insemination gun) dan plastic sheath dengan sheath cover yang dimasukkan ke lumen serviks sampai posisi cincin ketiga. Selanjutnya laras inseminasi dicabut, ujung plastic sheath dipotong $\pm 2 \mathrm{~cm}$ menggunakan gunting steril, dimasukkan kedalam tabung yang berisi larutan phophate buffered saline (PBS). Sampel disimpan dalam coolbox dengan ice pack dan dibawa ke laboratorium Bakteriologi Fakultas Kedokteran Hewan Unair.

\section{Pewarnaan Gram}

Suspensi bakteri dioleskan ke gelas obyek menggunakan ose, kemudian prepart difiksasi diatas api pembakar spiritus. Selanjutnya di atas bak warna, gelas obyek digenangi dengan pewarna karbol gentian violet selama satu menit, zat warna yang berlebih dibuang, lalu dibilas dengan air suling. Preparat digenangi lugol selama dua menit, lugol yang berlebih dibuang, kemudian dibilas dengan air suling. Preparat diberi alkohol $95 \%$ tetes demi tetes selama 30 detik atau sampai zat warna larut dan dibilas dengan air suling. Preparat digenangi lagi dengan larutan fuksin selama 30 detik, pewarna yang berlebih dibuang, dibilas dengan air suling, lalu dikeringkan dengan kertas saring. Preparat diperiksa dibawah mikroskop dengan perbesaran 1000 x. Pewarnaan Gram dilakukan setelah diketahui adanya koloni. Dengan pewarnaan Gram, bakteri gram positif tampak berwarna ungu sedangkan bakteri gram negatif akan tampak berwarna merah (Sunatmo, 2007).

\section{Uji katalase}

Uji katalase digunakan untuk melihat aktivitas enzim katalase pada bakteri sehingga dapat diketahui perbedaan jenis koloni yang terbentuk pada isolat yang diuji. Uji dilakukan dengan meneteskan Hidrogen Peroksida $\left(\mathrm{H}_{2} \mathrm{O}_{2}\right)$ $3 \%$ pada gelas obyek. Biakan dioleskan pada gelas obyek yang telah ditetesi $\mathrm{H}_{2} \mathrm{O}_{2}$ menggunakan ose. Hasil positif ditandai dengan adanya buih (Sunatmo, 2007). Uji katalase dilakukan untuk bakteri dengan morfologi 
Coccus gram positif dan Cocobacil gram negatif.

\section{Uji spora}

Uji spora dilakukan untuk membedakan apakah bakteri yang diuji dapat membentuk spora atau tidak pada bakteri dengan morfologi Bacill gram positif. Bakteri genus Corynebacterium tidak membentuk spora. Uji spora dilakukan dengan pewarnaan khusus spora menggunakan malachite green dengan proses pemanasan (Sunatmo, 2007).

\section{Identifikasi bakteri}

Dalam penelitian ini media Blood Agar (BA) digunakan untuk menumbuhkan bakteri gram positif maupun gram negatif dan media selektif yang digunakan untuk isolasi bakteri dengan karakteristik Coccobacillus gram negatif, Coccus gram positif, dan Bacillus gram negatif, adalah Eosin Methylene Blue Agar (EMBA), Mac Conkey Agar (MCA), dan Manitol Salt Agar (MSA). Identifikasi keberadaan bakteri dilakukan dengan mengamati pertumbuhan koloni bakteri pada media isolasi setelah diinkubasi selama 24 jam pada suhu $37^{\circ} \mathrm{C}$ (Handijatno et al., 2016).

Identifikasi genus bakteri dilakukan pada bakteri dengan morfologi Bacillus gram positif dan Cocobacillus gram negatif menggunakan media agar SIM dan TSIA. Media agar SIM digunakan untuk mengetahui zat yang diproduksi dan hasil-hasil pemecahan atau metabolisme bakteri. Media semi solid ini berfungsi mengetahui terbentuknya sulfide, indol, dan pergerakan bakteri. Media agar TSIA digunakan untuk menilai kemampuan bakteri memfermentasi glukosa, laktosa, dan sukrosa. yang ditandai dengan perubahan warna akibat timbulnya suasana asam, serta terbentuknya $\mathrm{H}_{2} \mathrm{~S}$ yang ditandai dengan perubahan warna media dari oranye menjadi hitam (Handijatno et al., 2016).

\section{HASIL}

Hasil identifikasi 20 sampel lendir serviks menunjukkan adanya bakteri genus Enterobacter, Staphylococcus, Corynebacterium, Streptococcus, Escherichia, dan Pasteurella (Tabel 1).
Tabel 1 Genus bakteri yang teridentifikasi (\%) pada lendir serviks sapi perah pada fase folikuler dan fase luteal.

\begin{tabular}{lcc}
\hline \multirow{2}{*}{ genus bakteri } & \multicolumn{2}{c}{ fase siklus birahi } \\
\cline { 2 - 3 } & folikuler & luteal \\
\hline Enterobacter & $100 \%$ & $80 \%$ \\
Staphylococcus & $100 \%$ & $80 \%$ \\
Corynebacterium & $60 \%$ & $40 \%$ \\
Streptococcus & $50 \%$ & $50 \%$ \\
Escherechia & $60 \%$ & $40 \%$ \\
Pasteurella & $40 \%$ & $40 \%$ \\
\hline
\end{tabular}

ulangan $=10$

Pewarnaan Gram menunjukkan empat macam morfologi bakteri, yaitu Bacillus gram negatif, Cocobacillus gram negatif, Coccus gram positif, dan Bacillus gram positif (Gambar $1)$.

\section{DISKUSI}

Jenis bakteri non spesifik yang teridentifikasi dalam lendir serviks sapi perah di Peternakan sapi perah masyarakat di Surabaya tidak berbeda antara sapi yang berada dalam fase folikuler dan fase luteal. Bentuk koloni dan morfologi bakteri non spesifik yang teridentifikasi sesuai dengan rujukan (Washington et al., 2006). Hasil identifikasi menunjukkan profil yang berbeda dibandingkan penelitian sebelumnya (Fadhilla, 2018) yang dilakukan di lokasi yang sama dengan penelitian ini (Peternakan di Bendul Merisi, Surabaya), namun tanpa membedakan fase birahinya, dengan bakteri non spesifik yang terindentifikasi adalah Escherischia sp. (50\%), Staphylococcus sp. (35,7\%), dan Corynebacterium sp. (14,3\%).

Beberapa penelitian menunjukkan variasi genus maupun persentase bakteri non spesifik pada saluran reproduksi sapi (Patel et al., 2019). Penelitian dengan membedakan fase folikuler dan fase luteal juga telah dilakukan pada sapi perah Friesian Holstein di lokasi yang berbeda (Koperasi Tunas Setia Baru, Pasuruan). Bakteri non-spesifik yang diisolasi pada fase folikuler adalah Staphylococcus sp. (50\%), Corynebacterium sp. (25\%), dan Escherichia sp. (25\%), sedangkan pada fase luteal, 
Staphylococcus sp. (45,5\%), Escherichia sp. (45,5\%), dan Corynebacterium sp. (9\%) (Sudrajad et al., 2018). Penelitian di India menunjukkan bahwa pada fase folikel dari siklus estrus, isolat bakteri yang paling dominan adalah Bacillus sp., diikuti oleh Corynebacterium sp., Staphylococcus sp., dan Streptococcus sp., sedangkan selama fase luteal bakteri yang paling dominan adalah Staphylococcus sp., diikuti oleh Corynebacterium sp., Bacillus sp., Escherichia sp., dan Streptococcus sp. (Patel et al., 2019). Meskipun terdapat variasi persentasenya genus bakteri, infeksi oleh bakteri non spesifik dapat mempengaruhi warna, konsistensi, $\mathrm{pH}$ lendir serviks dan gangguan ovulasi, sehingga menyebabkan kawin berulang (Bhat et al., 2015). Pada sapi yang mengalami kawin berulang $62,2 \%$ diantaranya terdeteksi bakteri, sedangkan pada sapi dengan kesuburan normal terdeteksi bakteri hanya 28,6\%. Pada sapi-sapi yang mengalami kawin berulang teridentifikasi bakteri Staphylococcus sp. (37,8\%), diikuti oleh Bacillus sp. (35,1\%), Escherichia sp. (29,7\%), Pseudomonas sp. $(18,9 \%)$, dan Bacillus gram negative $(24,3 \%)$ (Gani et al., 2008).

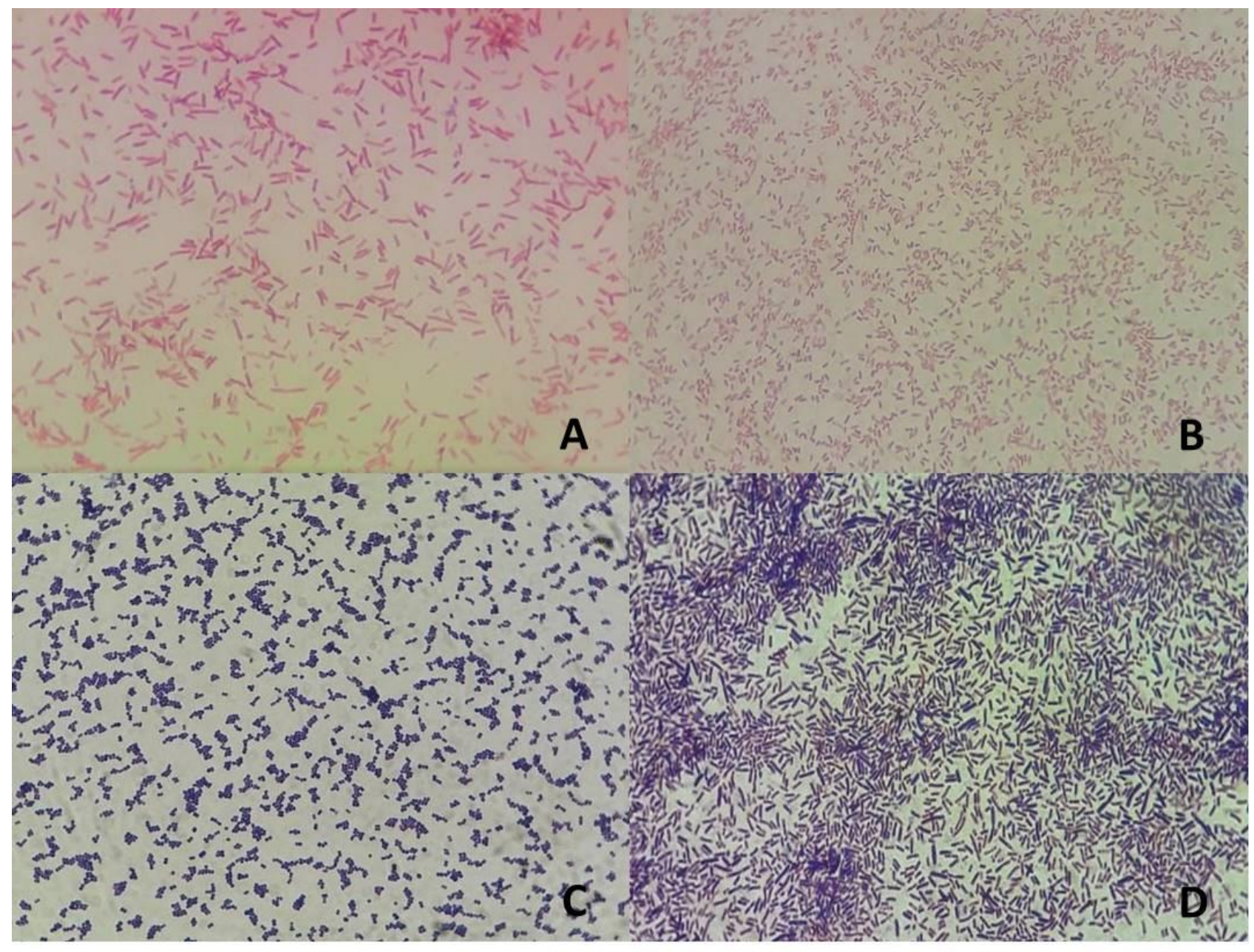

Gambar 1 Morfologi bakteri lendir serviks sapi perah pada fase folikuler dan fase luteal; A. bakteri Bacillus gram negatif; B. bakteri Cocobacillus gram negatif; C. bakteri Coccus gram positif; D. bakteri Bacillus gram positif; pewarnaan Gram; perbesaran 1000 x.

Pada fase folikuler kadar FSH yang dikeluarkan oleh kelenjar adenohipofisa akan memicu perkembangan folikel di dalam ovarium, bersama Luteinizing Hormone (LH) ovarium kemudian meningkatkan produksi estrogen melalui peningkatan cairan folikel. Pada fase ini juga terjadi perkembangan organ- organ reproduksi yaitu oviduk, uterus, dan vagina (Frandson, 2003). Beberapa spesies hewan mengalami pertumbuhan sel-sel dan lapisan bersilia pada oviduk, serta vaskularisasi mukosa uterus. Serviks mengalami relaksasi dan banyak mensekresikan mucus yang tebal dan berlendir dari sel-sel goblet serviks dan 
vagina anterior, serta kelenjar-kelenjar uterus. Estrogen dalam tubuh ternak akan mempengaruhi percabangan rantai molekul dalam lendir serviks. Enzim lisosom berperan sebagai perusak dinding sel bakteri yang berkoloni dalam lendir serviks yang dihasilkan ternak ketika berada pada fase estrus, sehingga semakin tinggi keberadaan lisosom, mikroba dalam lendir akan menurun dan lendir dapat keluar dalam bentuk bening (Kruse et al., 2000). Komposisi lendir serviks sebagian besar merupakan zat organik dengan efek antimikroba seperti lisozim, laktoferin, peroksidase, histatins, dan immunoglobin (Hafez dan Hafez, 2000). Lisozim adalah enzim yang dapat memecah peptidoglikan yang merupakan komponen penting dalam dinding sel bakteri gram positif dan menghambat aglutinasi bakteri yang memiliki muatan positif yang kuat. Laktoferin memiliki efek bakterisida, fungisida, dan sebagai antivirus (Pelczar et al., 2008; Iman et al., 2011). Seharusnya pada fase folikuler bakteri cenderung sedikit ditemukan dibandingkan dengan fase luteal. Namun, pada hasil penelitian ini, bakteri non spesifik pada fase folikuler lebih banyak dibandingkan fase luteal. Hal ini membuktikan bahwa terbukanya serviks dapat menyebabkan masuknya bakteri ke dalam saluran reproduksi sapi perah secara cepat, sehingga pada fase folikuler bakteri yang teridentifikasi lebih banyak dibandingkan pada fase luteal.

Secara normal bakteri non spesifik tidak menyebabkan gangguan saluran reproduksi sapi betina, tetapi apabila terdapat luka maka bakteri non spesifik tersebut menjadi patogen dan menyebabkan peradangan, antara lain vaginitis, servisitis, maupun endometritis, dan dapat menimbulkan kawin berulang.

\section{KESIMPULAN}

Bakteri non spesifik genus Enterobacter, Staphylococcus, Corynebacterium, Streptococcus, Escherichia, dan Pasteurella teridentifikasi dalam lendir serviks sapi perah pada fase folikuler dan fase luteal dengan persentase bervariasi.

\section{DAFTAR PUSTAKA}

Bhat FA, Bhattacharyya HK, Fazili MR, Hussain SA, Khan MZ. 2015. Studies on estrual cervical mucus of repeat breeding cows with special reference to ovulatory disturbances and genital infection. Theriogenology Insight 5: 113-23.

Fadhilla GF. 2018. Isolasi bakteri non spesifik pada saluran reproduksi sapi perah yang dikawinkan secara alami dan secara Inseminasi Buatan. Skripsi. Fakultas Kedokteran Hewan. Universitas Airlangga.

Frandson RD. 2003. Anatomi dan Fisiologi Ternak. Edisi ke-7. Gadjah Mada University Press. Yogyakarta.

Gani MO, Amin MM, Alam MGS, Kayesh MEH, Karim MR, Samad MA, Islam MR. 2008. Bacterial flora associated with repeat breeding and uterine infections in dairy cows. Bangl J Vet Med. 6: 79-86.

Hafez ESE, Hafez B. 2000. Reproductive Cycles. Dalam: Hafez B, Hafez ESE (Ed). Reproduction in Farm Animals. 7th ed. Lippincott William \& Wilkins. A Wolter Kluwer Company. 55-67.

Handijatno D, Tyasningsih W, Narumi HE, Sarudji S, Chusniati S. 2016. Penuntun Praktikum Mikrobiologi Veteriner I Program Studi S-1. Fakultas Kedokteran Hewan. Universitas Airlangga. Surabaya.

Hariadi M, Hardjopranjoto S, Wurlina W, Hermadi HA, Utomo B, Rimayanti R, Triana IN, Ratnani H. 2011. Ilmu Kemajiran Pada Ternak. Cetakan 1. Airlangga University Press. Surabaya.

Iman ERS, Ratnasari R, Narumi HE, Suryanie S, Tyasningsih W, Chusniati S. 2011. Buku Ajar Mikrobiologi Veteriner I. Cetakan 1. Airlangga University Press. Surabaya.

Ismudiono I, Srianto P, Anwar H, Madyawati SP, Samik A, Safitri E. 2010. Buku Ajar Fisiologi Reproduksi pada Ternak. Penerbit: Airlangga University Press. Surabaya.

Kruse M, Strandberg M, Strandberg B. 2000. Ecological Effects of Allelopathic Plants-A Review. National Enviromental Research Institute - NERI Technical Report No. 315. Silkeborg, Denmark. 
Patel CI, Panchal MT, Dhami AJ, Bhanderi BB, Mathakiya RA. 2019. Isolation of bacteria from the vaginal aspirates of cyclic, acyclic, endometritic and pregnant crossbred cows. Int J Curr Microbiol App Sci. 8: 536-42.

Pelczar MJ, Chan ECS. 2008. Dasar-dasar mikroorganisme. Universitas Indonesia Press. Jakarta.

Sanny L. 2011. Analisis industri pengolahan susu di Indonesia. Binus Bussines Review. 2:81-87.

Sudrajad K, Madyawati SP, Tyasningsih W, Rimayanti R, Srianto P, Widodo OS. 2018. Bacterial isolates from the cervical mucus of dairy cattle at follicular and luteal phases. Philipp J Vet Med. 55: 121-26.
Sunatmo TI. 2007. Eksperimen Mikrobiologi dalam Laboratorium. Penerbit Ardy Agency. Bogor.

Wahyuni ES. 2012. Potensi Genetik Produksi Susu Sapi Friesian Holstein Betina di BBPTU Sapi Perah Baturaden, Purwokerto [Skripsi]. Fakultas Peternakan. Institut Pertanian Bogor.

Winn W, Allen S, Janda W, Koneman E, Procop G, Schreckenberger P, Woods G. 2006. Color Atlas and Textbook of Diagnostic Microbiology. $6^{\text {th }}$ Ed. Lippincott Williams \& Wilkins. Philadelphia. 111-131. 